UDK: 81'42

DOI: 10.33669/KJ2021-32-01

primljeno / received: 6. 10.2021.

prihvaćeno / accepted: 4. 12.2021.
Izvorni naučni rad

\section{Bernes Aljukić}

Univerzitet u Tuzli, Filozofski fakultet Odsjek za bosanski jezik i književnost Dr. Tihomila Markovića 1, 75000 Tuzla, Bosna i Hercegovina Druga osnovna škola Srebrenik Ulica Meše Selimovića b. b., 75350 Srebrenik, Bosna i Hercegovina bernes.aljukic@bih.net.ba

\title{
Rodno označena referencijalnost u medijskom diskursu
}

Sažetak: U paleti konverzacijskih strategija kojima se ističu pretpostavljene razlike u komunikacijskim stilovima muškaraca i žena prepoznaje se i konverzacijski fenomen referencijalnosti, uočen još 70-ih godina prošlog stoljeća - da žene, češće od muškaraca, na počecima svojih iskaza eksplicitno naglašavaju ono što je ranije rečeno i tim postupkom grade konverzacijsku jezgru. Cilj rada, stoga, jeste utvrditi prisutnost i konverzacijsku posljedičnost takve pojave u medijskom diskursu analizom konverzacijskih parova u televizijskim intervjuima s ravnopravno zastupljenim gostima / gošćama i voditeljima / voditeljicama. Konverzacijskom i diskursnom analizom, te primjenom kompjuterskog programa Elan, korisnog alata za transkripciju i anotaciju, obuhvaćen je dvoslojni korpus od 13 intervjua, koji se sastoji od oko 73.000 riječi. Uz sva ograničenja korpusa i metodologiju koju ovakav pristup nosi, analizom se pokazuje da su prepoznatljive četiri moguće konverzacijske i pragmatičke funkcije referencijalnosti u medijskom diskursu, uz tu razliku da se češće uočavaju u muškim konverzacijskim parovima. Referencijalnost u medijskom diskursu implicira sljedeće pragmatičke funkcije: podrška sugovorniku, ojačanje vlastitog iskaza, poticanje konverzacijskog toka te pojašnjavanje ili zahtjev za dopunu informacije. Češće se prepoznaje u intervjuima s muškim voditeljem i s muškim konverzacijskim parovima.

Ključne riječi: rod, jezik, TV-intervjui, referencijalnost, TCU 


\section{Uvod}

Bavljenje složenom vezom roda i rodno označene upotrebe jezika teško da je moguće krene li se u potragu za hipotetičkim unitarnim pristupom kojim bi se dobili čvrsti i nepokolebljivi rezultati. Tako Sunderland (2006: 55-58) prepoznaje da se u istraživanju složene veze roda i jezika ističu metode introspekcije, sociolingvističkih istraživanja, korpusne analize, analize fokusnih grupa, a paleti metodoloških pristupa tom polju Wooffitt (2005: 1) pridodaje konverzacijsku analizu, diskursnu analizu, diskurzivnu i retoričku psihologiju, teoriju govornih činova, kritičku diskursnu analizu te fukoovski pristup diskursu.

Uočljivo je da se u analizi rodno označene upotrebe jezika ili analizi rodno označenih jezičnih resursa eo ipso - ako je o jeziku uopće moguće tako razmišljati - promatraju suprotstavljeni dijelovi dihotomije "muškarci žene" i to tako što se prednost obično daje naglašavanju i produbljivanju razlika između komunikacijskih stilova muškaraca i žena, pri čemu se, kako to ističu Eckert i McConnel-Ginet (2003: 123), često zanemaruju međusobne sličnosti. Hijerarhijska asimetričnost takve dihotomije vidi se po tome što se muški stil konverzacije obično nameće kao objekt težnje, dok bi pribjegavanje ženskom stilu komunikacije značilo pretpostavljeno potvrđivanje slabosti vlastite komunikacijske kompetencije.

Priroda navedenog odnosa potvrđuje se već 80-ih godina prošloga stoljeća kada su O’Barr i Atkins (1980: 401-407) u analizi konverzacijskih stilova i strategija u sudskim procesima zaključili da je porota bila naklonjenija onim govornicima koji su se udaljavali od svojstava "govora nemoćnih". O problemu pretpostavljene homogenosti, odnosno o statičnom, pretjeranom dualizmu, Talbot (2003) govori s obzirom na pogrešne pretpostavke o "fiksiranim" razlikama muških i ženskih komunikacijskih stilova. Savremeni pristupi opravdano se usmjeravaju na znatno uža područja radnih zajednica, pri čemu se rezultati istraživanja interpretiraju isključivo u takvom kontekstu, a generalizacije se pažljivo zaobilaze jer su odraz površnog ili stereotipnog pristupa toj tematici.

U vezi sa ženskim načinom konverzacijske interakcije obično se naglašavaju pretpostavljena ženska nemoć i susretljivost, odnosno 
izraženija obazrivost žena prema sugovorniku / sugovornici. Pored ostalih, Cameron (1985. u Talbot 2003: 476) izdvaja feministička pučkolingvistička uvjerenja o ženskome govoru: disfluentnost (jer je ženama teško komunicirati u svijetu muškaraca), češću nedovršenost rečenica, odstupanja od logičke uređenosti govora, upotrebu iskaza u formi pitanja (u svrhu traženja podrške), žene manje govore od muškaraca $\mathrm{u}$ rodno miješanim grupama i prednost daju strategiji saradnje, dok muškarci preferiraju strategiju natjecateljstva.

Podsjećanja radi, istraživanja te vrste započinju od 1970-ih godina kada R. Lakoff (2004: 19-75) prepoznaje jezična sredstva koja su u službi umekšavanja i ublažavanja vlastitog ženskog mišljenja ili uvjerenja: privjesna pitanja (engl. tag questions), uzlaznu intonaciju na deklarativima, upotrebu raznolikih govornih graničnika, upotrebu pojačivača, indirektnost, upotrebu deminutiva i eufemizama te izraženiju uljudnost negoli kod muškaraca.

Coates (2004: 108) izdvaja rezultate do kojih su došli spomenuti O’Barr i Atkins (1980) koji popisu R. Lakoff pridodaju i težnju žena da u komunikaciji više direktno citiraju, da primjenjuju hiperkorektnu gramatiku, preciznije označavaju boje i pokazuju slabiji uspjeh u pričanju šala.

U sličnim se zaključcima može prepoznati i to da žene u komunikaciji postavljaju više pitanja, koriste pozitivne minimalne odgovore, više koriste lične zamjenice "ti" i "mi" te više primjenjuju strategiju "tihog protesta" kada bivaju prekinute u konverzaciji (obično od muškaraca). Takve zaključke Maltz i Borker (1982: 197-198) navode uz suprotna svojstva muškoga govora: češće prekidanje sugovornika, propitivanje i izražavanje sumnje u rečeno, ignoriranje komentara sugovornika, češće primjenjivanje mehanizama kontrole konverzacije i češće iznošenje vlastitog mišljenja i stavova.

Jedno od posebnih svojstava ženskoga stila konverzacije navodi Kalčik (1975. u Sunderland 2006: 118-119) koja prepoznaje da na početku vlastitoga iskaza žene eksplicitno naglašavaju i odgovaraju na ono što je ranije rečeno. Takva težnja da se vlastiti iskaz poveže s nekim ranijim iskazom odražava težnju žena da stvore konverzacijski kontinuitet. 
Time se, smatra autorica, iskazuje orijentiranost prema sugovorniku i daje dinamičnost konverzacijskom toku. Tako se konverzacija oblikuje na osnovi uzajamne interakcije učesnika konverzacije prije negoli da je određena postupcima individue ili grupe individua. Narativna jezgra tako postaje resurs i za individuu i za grupu koja sudjeluje u konverzaciji.

U ovom se radu govori upravo o takvim komunikacijskim strategijama i to tako što se promatraju u medijskom diskursu, pri čemu se u interpretacijskom okviru u obzir uzimaju upravo svojstva tog diskursa s obzirom na asimetričnost odnosa moći u konverzacijskom događaju.

\section{Teorijski okvir}

Budući da su predmetom istraživanja televizijski intervjui, s korpusnom analizom kombiniraju se diskursna (DA) i konverzacijska analiza (KA). Takav spoj ojačan je činjenicom da se obje analize usmjeravaju na govor kao predmet istraživanja, pri čemu KA odstupa od bilo kakve mogućnosti apriorne "kontaminacije rezultata", kako to nazivaju Speer i Stokoe (2011: 25). U takvom eklektičnom spoju važno je naglasiti da se konverzacijskoanalitičkim pristupom upravo ograničava primjena bilo kakvog eksternog, unaprijed zadanog skupa pravila o konverzaciji, kao i generalizacija dobivenih rezultata na izvankorpusni prostor, već je predmetom analize sama konverzacijska interakcija koja se promatra kao dostatan objekt analize. Takav je pristup upravo ono u čemu je KA bliska etnometodološkom modelu, onom koji zaobilazi pretpostavljenu neupitnost teorijskog modela čije se zakonitosti promatraju u praksi jer se, u tom pristupu (etnometodološkom), analizirani fenomen promatra upravo obrnuto, tj. iznutra prema vani. Dakako, u pogledu primjene diskursnoanalitičke metodologije, ipak je važno istaknuti potrebu razumijevanja dodijeljenih govornih uloga u medijskom diskursu; riječ je primarno o asimetričnom odnosu učesnika konverzacije jer odnos govornika i sugovornika u televizijskom intervjuu nije ravnopravan niti oni imaju na raspolaganju iste jezične resurse.

Složenost takvog suživota DA i KA dodatno se prepoznaje u odnosu KA prema pravilima o konverzaciji, tom (oksimoronski rečeno) 
duboko organiziranom, ali spontanom fenomenu. Dakako, KA prednost daje analizi spontanih razgovora, za razliku od DA koja se usmjerava na konverzaciju unutar jasno određene institucionalizirane situacije. U vezi s problemom pravila i KA vrijedi podsjetiti na mišljenje Searla (1986: 18, u Hutchby - Wooffitt 2002: 50), koji ističe da pravila o izmjenama govornika unutar KA čak i ne izgledaju kao prava pravila jer ne preciziraju sadržajnu namjeru koja bi imala ključnu ulogu. Nasuprot njemu, Button (1990: 79, u Hutchby - Wooffitt 2002: 51) svojstvo pravila $\mathrm{u}$ KA prepoznaje u orijentiranosti govornika u samoj primjeni pravila, pri čemu se pravilo promatra kao dio logičke gramatike radnje. Ne postoje pravila koja su internalizirana i koja bi takva uzrokovala radnju jer pravilo kako ga vidi KA ne prethodi radnji upravo zato što je prepoznatljivo u samoj radnji. Dakako, u tom je pristupu prepoznatljiva spomenuta etnometodološka koncepcija pravila, a vrijedi podsjetiti na to da i KA i DA imaju vezu s etnometodologijom od koje nasljeđuju mišljenje o skrivenom, prešutnom znanju članova zajednice te o interpretacijskim praksama o određenim društvenim aktivnostima, koje se promatraju nasuprot zadanim eksternim teorijskim modelima.

Wooffitt (2005: 71-88) razlike između diskursne i konverzacijske analize objašnjava time što se KA bavi nizom konverzacijskih radnji koje su međusobno povezane, a ne pojedinačnim iskazima te se primarno usmjerava na interakciju. Diskursna analiza bavi se skupom širih jezičnih praksi, onim elementima teksta ili govora u kojima se izriču mišljenja, oblikovane verzije događaja i sl. "izvantehničkim” elementima. U tome se vidi ključna razlika između tih dviju vrsta analize: KA istražuje kako učesnici organiziraju interakciju u njezinom samom slijedu, opisuje kako se ostvaruju visoko organizirani dijelovi sekvencijske strukture, otkriva metode za prijenos govornih uloga, prepoznavanje problema, nesporazuma, pogrešaka i ispravaka itd. KA je u tome smislu vrlo minuciozan pristup jer nastoji obuhvatiti što potpuniju sliku konverzacijske interakcije u cijelosti. Nasuprot KA, diskursna analiza nalazi se na širem nivou, a empirijska analiza teksta ili govora uključuje i šire lične ili društvene funkcije. Širi analitički fokus diskursne analize vidi se i u tome što se rijetko govori o interakcijskim svojstvima "per se". 
DA i KA razlikuju se i u vrstama podataka s obzirom na to da se diskursni analitičari bave širim opsegom i vrstama podataka u odnosu na klasične podatke zastupljene u KA. DA se više bavi kontroverznim i neobičnim podacima, dok KA teži analizi onih koji su uobičajeni i naizgled beznačajni jer je riječ o rutinskim aktivnostima svakodnevne konverzacijske interakcije radi ostvarenja određenog konverzacijskog cilja. Takvih aktivnosti bivamo svjesni tek kada se uobičajena rutina narušava (što su npr. pokazali tzv. pokusi probijanja - o čemu govore Hutchby i Wooffitt 2002: 30-35).

Sunderland uočava da je rodni diskurs posebno pitanje u takvim istraživanjima budući da su ona usmjerena na interakcijsku dominaciju u konverzacijama miješanih rodnih grupa. Muška dominacija u tim okolnostima prepoznaje se u tome što muškarci češće i više govore negoli žene, češće prekidaju sugovornike/-ce, iskazuju manje minimalnih odgovora, postavljaju manje pitanja i bolje iznose svoje teme negoli to uspijeva ženama (Sunderland 2006: 53).

Asimetričnost konverzacijskih uloga posebno je pitanje u kritičkoj diskursnoj analizi, koja je ogranak diskursne analize usmjeren na koncept moći u institucionalnoj dominaciji. Tako Mills (2003: 48) uočava da je jedno od posebnih pitanja i pitanje moći u asimetričnim govornim parovima gdje se vrlo često nameće potreba razmatranja stereotipa jer se, npr., očekuje da žene u ulozi institucionalne moći imaju manje takve moći negoli muškarci. Mills (2003: 179) ujedno ističe da je upravo interakcijska moć u konverzaciji jedna od najčešćih varijabli koja se uzima u obzir u takvim istraživanjima. Također prepoznaje da se u istraživanjima konverzacije u vođenju sudskih sporova uočava da muškarci koji su u podređenoj ili bespomoćnoj situaciji pokazuju govorne odlike koje su vrlo bliske stereotipnim predodžbama o ženskom govoru. Dakako, koncept moći odnosi se na interakcijsku dominaciju, onako kako je predstavljaju Bousfield i Locher (2008: 9), pri čemu ističu da se moć ostvaruje u strategijskom ograničavanju radnji i okruženja sugovornika. 


\section{Metodologija i korpus}

Korpus istraživanja sastoji se od ukupno 16 transkripata (oko 73.000 riječi). Čine ga televizijski intervjui bosanskohercegovačkih televizijskih kuća FACE TV i TV1, a predmetom su analize intervju s televizije Al Jazeera Balkans i dva intervjua s Hrvatske radiotelevizije. U televizijskoj kući FACE TV intervju je dio središnje informativne emisije Centralni dnevnik, u televizijskoj kući TV1 to je emisija Petkom s Nikolinom; Recite Al Jazeeri dijaloška je emisija televizije Al Jazeera Balkans, a Nedjeljom u 2 emisija Hrvatske radiotelevizije. Ovo istraživanje, u odnosu na slična, prednost ima u tome što su predmetom analize isti konverzacijski parovi, dakle isti voditelji i isti gosti, s pripadajućim višestrukim kombinacijama u međusobnoj konverzaciji. Korpus je uvjetovan dostupnošću takvih intervjua u medijskom prostoru u Bosni i Hercegovini i susjedstvu te je tada bilo moguće izdvojiti pet gostiju koji su gostovali kod dvoje istih voditelja (voditelja i voditeljice). Od pet gostiju, dvije su gošće (jedna je književnica i kardiolog, druga politička analitičarka), a tri su gosta političari. S obzirom na hijerarhijski asimetrične diskursne i rodne uloge u intervjuu kao žanru, predmetom analize su i voditelji i njihovi gosti, odnosno konverzacijski parovi predstavljeni na pripadajućim grafičkim prikazima.

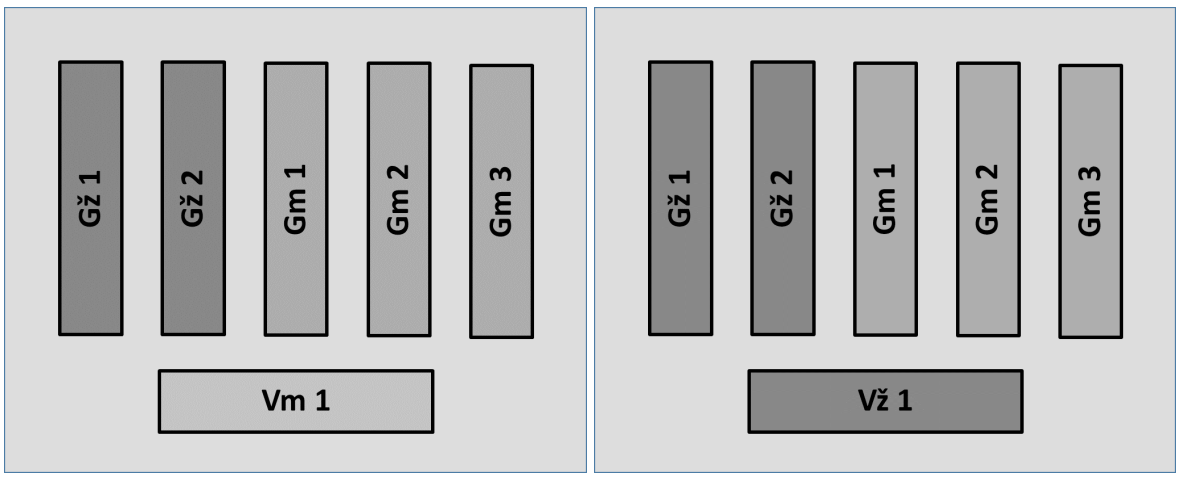

Slika 1: Konverzacijski parovi Vm1 i Vž1 s pripadajućim gošćama i gostima (ukupno 10 intervjua) ${ }^{1}$

1 Objašnjena skraćenica: Vm = voditelj (muškarac), Vž = voditeljica (žena), Gm = gost (muškarac), Gž = gošća (žena); broj uz skraćenicu odnosi se na pripadajućega gosta/gošću. 
Odabranih deset intervjua čine korpusnu jezgru jer su učesnici tih konverzacijskih događaja isti. S obzirom na složenost njihovih međusobnih odnosa, analiza korpusne jezgre odvija se dvosmjerno, što znači da se najprije dolazi do rezultata o voditelju i voditeljici prema svakom gostu i gošći, zatim o svakom gostu i gošći pojedinačno u odnosu na voditelje te zbirno za voditelje i sve goste i gošće. Cjelokupna transkripcija videozapisa obavljena je pomoću kompjuterskoga programa Elan Linguistic Annotator. ${ }^{2}$

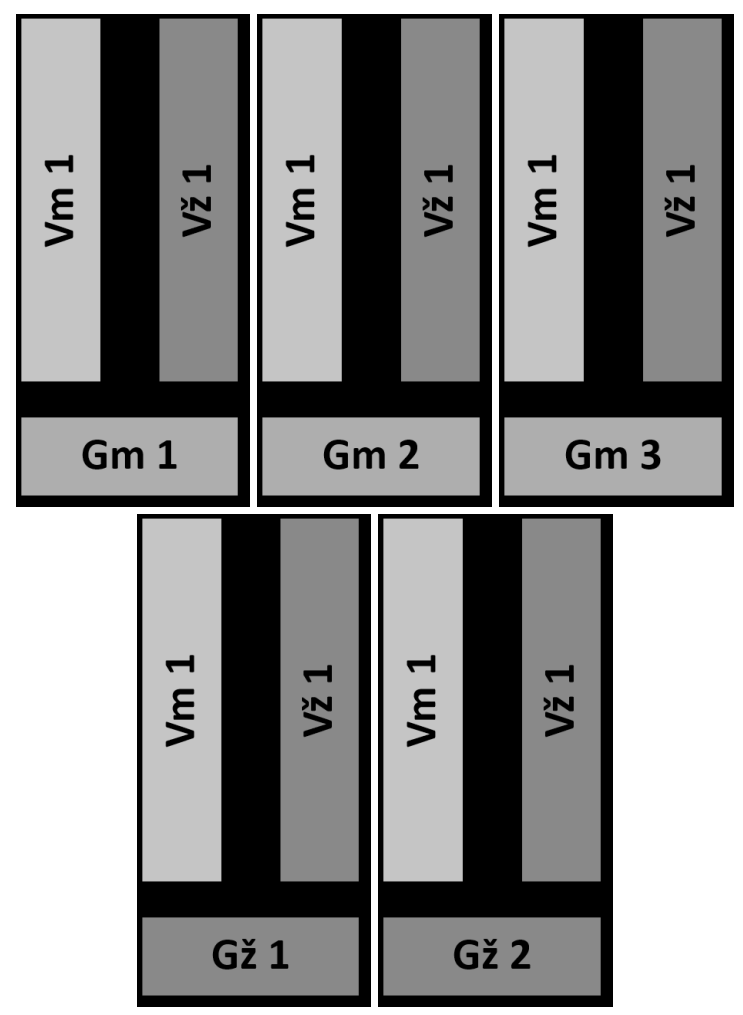

Slika 2: Konverzacijski parovi svakoga gosta i gošće posebno s voditeljem Vm1 i voditeljicom Vžl (korpusna jezgra)

2 https:/tla.mpi.nl/tools/tla-tools/elan/ (dostupno u novembru 2021). Elan Linguistic Annotator program je vrlo široke primjene za slična istraživanja. Iako ne vrši automatsku transkripciju, pruža mnoge mogućnosti za analizu audio/ videozapisa. 
Specifičnost korpusne jezgre jeste u neravnopravnom odnosu gostiju i gošći (3:2), pa se uvođenjem dodatnih dvaju intervjua jezgra proširuje u dijelu analize odnosa gošće prema voditelju i voditeljici. Dodatni intervjui jesu gostovanja gošće Gž3 (političarke) kod voditeljice Vž2 (Al Jazeera Balkans, emisija Recite Al Jazzeri) te gostovanje iste gošće Gž3 kod voditelja Vm2 (HRT, emisija Nedjeljom u 2). Ulaskom dodatne gošće dobio se proporcionalan odnos svih gostiju u skladu s rodnim ulogama: 3 gosta i 3 gošće.

Iz istog razloga proporcionalne ravnopravnosti izvršeno je dodatno proširenje korpusne jezgre tako što se uveo dodatni voditelj jer se prethodnim proširenjem uvela dodatna voditeljica. Tako se, u konačnici, dobio ravnopravan broj gostiju i gošći naspram voditeljima i voditeljicama.
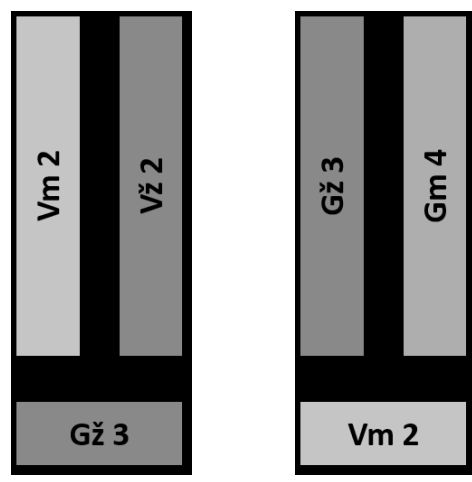

Slika 3: Proširenje korpusne jezgre dodatnim konverzacijskim parovima radi proporcionalnog odnosa i rodne zastupljenosti učesnika intervjuā

Dakle, dvoslojni korpus sastoji se od trinaest intervjua. Tu, sveukupno gledano, imamo dva voditelja, dvije voditeljice, tri gošće i tri gosta. Tabelarni prikaz korpusne jezgre, dodatka jezgri i korpusnog dodatka izgleda ovako: 
Tabela 1. Prikaz korpusne jezgre i korpusnog dodatka

\begin{tabular}{|c|c|c|c|}
\hline $\begin{array}{l}\text { R. br. } \\
\text { intervjua }\end{array}$ & $\mathrm{Vm} / \mathrm{Vž}$ & $\mathrm{Gm} / \mathrm{Gž}$ & \multirow{7}{*}{$\begin{array}{l}\text { KORPUSNA JEZGRA } \\
\text { (intervjui 1-10) }\end{array}$} \\
\hline 1. & Vm 1 & Gž 1 & \\
\hline 2. & $\mathrm{Vm} 1$ & Gž 2 & \\
\hline 3. & $\mathrm{Vm} 1$ & Gm 1 & \\
\hline 4. & Vm 1 & $\mathrm{Gm} 2$ & \\
\hline 5. & Vm 1 & $\mathrm{Gm} 3$ & \\
\hline 6. & $V_{z ̌} 1$ & Gž 1 & \\
\hline 7. & V̌̌ 1 & Gž 2 & \multirow{7}{*}{$\begin{array}{l}\text { KORPUSNI DODATAK } \\
\text { (intervjui 11-13) }\end{array}$} \\
\hline 8. & V̌̌ 1 & Gm 1 & \\
\hline 9. & V̌̌ 1 & Gm 2 & \\
\hline 10. & Vž 1 & Gm 3 & \\
\hline 11. & Vž 2 & Gž 3 & \\
\hline 12. & $\mathrm{Vm} 2$ & $\mathrm{Gž} 3$ & \\
\hline 13. & $\mathrm{Vm} 2$ & $\mathrm{Gm} 4$ & \\
\hline
\end{tabular}

Uz navedenih trinaest intervjua, svoje su mjesto našla još tri intervjua istog voditelja Vm1 i voditeljice Vž1 s drugim gostima. Ilustrativnosti radi, u odabranim primjerima u ovom radu uzeto je nekoliko dijelova iz tih dodatnih transkripata. $U$ tabelarnom prikazu u idućem dijelu rada, kvantitativno gledano, ubrojeni su samo primjeri intervjua navedenih u tabeli 1.

\section{Rezultati i zaključci}

S obzirom na dominantnu odrednicu KA da je predmetom istraživanja konverzacijska struktura u cijelosti, odnosno da se analitičari bave sekvencijskim slijedom TCU jedinica ${ }^{3}$ i orijentiranošću učesnika konverzacije prema konverzacijskim radnjama koje prethode njihovom govornom prilogu, u ovome dijelu analize razmatra se referencijska povezanost TCU jedinica u takvome slijedu. U pojednostavnjenoj transkripciji (u odnosu na temeljna načela za transkripciju KA), korištene su sljedeće oznake:

3 TCU (engl. turn construction unit) - jedinica govornoga slijeda; uvjetno rečeno, riječ je o govornom "pseudopandanu" rečenici; TCU ima sličnost s iskazom (kontekstno "življom” rečenicom), no za razliku od iskaza, TCU ne mora imati svojstva gramatičnosti, nego se promatra kao doprinos konverzaciji i definira se s pragmatičkog, sintaktičkog ili intonacijskog aspekta; u ulozi TCU mogu biti rečenice, ali i pojedinačne riječi (uključujući i brojne "periferne" jezične elemente). 
Tabela 2. Simboli korišteni u pojednostavnjenoj transkripciji

\begin{tabular}{ll}
\hline simbol & značenje \\
\hline$(||)$ & $\begin{array}{l}\text { apsolutna bliskost (idealno uvezivanje TCU jedinica u govor- } \\
\text { nom slijedu) }\end{array}$ \\
\hline$!(1.5)$ & $\begin{array}{l}\text { konverzacijski prekid; trajanje u zagradi u sekundama (vrijeme } \\
\text { "zadiranja" u sugovornikovu TCU) }\end{array}$ \\
\hline$(1.5)$ & $\begin{array}{l}\text { preklapanje; trajanje u zagradi u sekundama (vrijeme "zadira- } \\
\text { TCU }\end{array}$ \\
\hline$(1.5)$ & razmak u sugovornikovu TCU) \\
\hline
\end{tabular}

Posebno treba naglasiti da je vrijednost u zagradama vrijeme koje se odnosi na pripadajući konverzacijski fenomen uz koji se ovdje navodi. Naime, riječ je o vrijednosti svojevrsne "govorne inercije", odnosno pojave da prekinuti ili preklopljeni govornik nastavlja govoriti istovremeno sa sugovornikom koji ga prekida. Rijetko se dešava da se prestaje govoriti istog trenutka kada govornik biva prekinut. Označavanjem vrijednosti dužine trajanja simultanoga govora ujedno se ukazuje na intenzitet "zadiranja" u govornikovu TCU (koja se prekida ili preklapa), uz polazište da je veća vrijednost odraz većeg intenziteta takvoga postupka. Takve informacije, pored ostalih, moguće je dobiti primjenom spomenutog Elana.

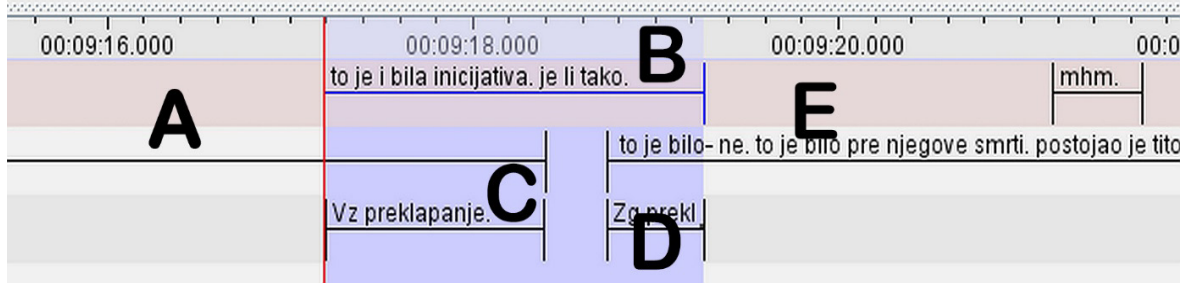

Slika 4. Prikaz dijela transkripta iz Elan Linguistic Annotator

Shematski prikaz pokazuje odvijanje govornoga preklapanja onako kako se najčešće realizira u svakodnevnoj komunikaciji. U prikazu je pojašnjenje oznaka sljedeće: $\mathrm{A}=$ dio na dovršetku TCU trenutačne govornice, $\mathrm{B}=\mathrm{TCU}$ voditeljice intervjua, $\mathrm{C}=$ označeno voditeljicino preklapanje gošćine TCU, D = gošćino preklapanje voditeljicine TCU, E = nova gošćina TCU. 
Takvi primjeri daju jasniji pogled na strukturu svakodnevne spontane konverzacije jer pokazuju da u međusobnoj konverzacijskoj interakciji konverzaciju realiziramo drukčije od uobičajenoga poimanja da sljedeći govornik započinje govoriti tek kad trenutni završi.

$\mathrm{U}$ vezi s tim, potpunije se može razumjeti pojava kada izostaje takav simultani govor, kao što vidimo na primjeru apsolutne bliskosti.

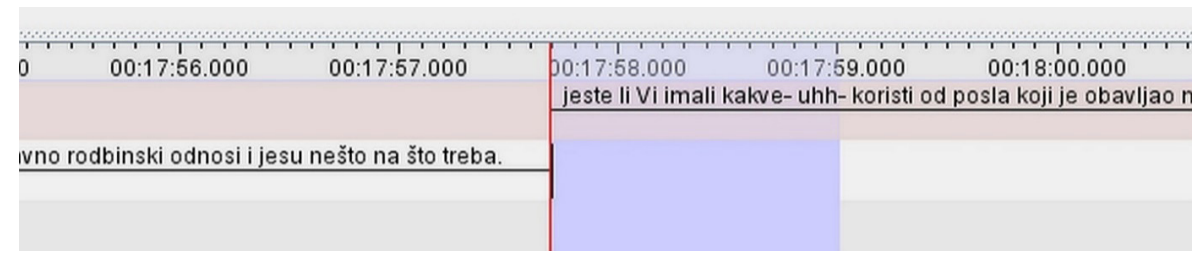

Slika 4. Prikaz apsolutne bliskosti

Uzimajući u obzir da se same TCU mogu sastojati od pojedinačnih riječi, fraza ili potpunih iskaza, ponavljajući dijelovi prethodnih TCU mogu se javiti podjednako i kao dijelovi te TCU (riječ, fraza ili cijela rečenica) ili kao potpuno identična preslika cijele višestruke TCU.

Iako se referencijska povezanost TCU jedinica općenito može razumjeti u vezi s očuvanjem konverzacijskog dinamizma, u korpusu se mogu prepoznati i specifične funkcije takvih konverzacijskih postupaka.

\section{Funkcija podrške sugovorniku \\ (potvrdivanje, slaganje sa sugovornikom)}

Ta se funkcija ostvaruje ponavljanjem dijela ili cijele prethodne TCU čime se gradi "zajedničko tlo", odnosno riječ je o fenomenu sličnom izopraksizmu, prepoznatljivom osobito u neverbalnoj komunikaciji (kakvo je, npr., ritmično rukovanje, potvrdno klimanje glavom ili slično oponašanje sugovornikova pokreta); ilustrativan primjer ovog jezičnog fenomena u verbalnoj izvedbi jest pozdravljanje, odnosno iskazivanje sustavnosti u strukturi susjednih parova tako što se ponavljaju riječi koje su nam upućene. 
TCU 38: $\quad$ Gm5: jeste. to ste- divno ste to rekli. jer mi svi u malim sredinama-

TCU 44: $\quad !(0,0)$ Vm1: tačno znate ko je- ko- ko je kakav. ko je ko.

TCU 39: $\quad(1,628)$ Gm5: jeste. znamo mu oca. znamo mu majku. znamo $\mathrm{mu}-$

TCU 45: ! $\quad$ (0,123) Vm1: ženu.

TCU 40: $\quad(0,273)$ Gm5: ženu. djecu.

TCU 46: $\quad(0,634)$ Vm1: ljubavnicu.

TCU 41: $\quad(0,100)$ Gm5: ljubavnicu.

TCU 47: $\quad(0,878)$ Vm1: djevojku. curu.

TCU 42: $\quad$ (\|) Gm5: djevojku. curu.

TCU 48: $\quad(0,304) V m 1$ : je l' ukr'o. nije ukr'o.

TCU 43: $\quad$ Gm5: je l' ukr'o. nije ukr'o.

TCU 49: $\quad=(1,184)=$ Vm1: koliko je ukr'o.

$(0,104)$

TCU 44: $\quad$ Gm5: jeste. koliko je ukr'o.

TCU 50: $\quad$ Vm1: o'kle mu.

TCU 45: Gm5: da. i- i- i- zanimljivo ste sad otvorili još jedno pitanje. Korpus, intervju Vm1/Gm5, korpusni dodatak

Voditelj Vm1 u primjeru TCU 44 prekida sugovornika, odnosno dovršava putanju njegove TCU 38. Gost Gm5 u istom trenutku prestaje govoriti i sluša dovršetak vlastite TCU. Gost Gm5 ne pokazuje želju da ustraje u svome govornom prilogu i trenutno prestaje govoriti. U TCU 39 gost Gm5 ostvaruje podupiruće govorno preklapanje zadirući u voditeljevu TCU za vrijednost veću od 1,5 sekundi, pri čemu se odvija simultani govor. U TCU 45 voditelj Vm1 ponavlja prethodni postupak te još jednom prekida sugovornika, dovršavajući njegovu TCU 39. Slijed idućih TCU jedinica pokazuje da su TCU gosta Gm5 zapravo identične 
preslike voditeljevih TCU. Upotreba potvrdnih “jeste”, “jeste”, “jeste” "da”, kao i uočljivog komplimenta upućenog voditelju Vm1 u TCU 38 ("divno ste to rekli") ide u prilog tvrdnji da se anaforička veza između TCU jedinica od hijerahijski podređenog člana konverzacijskog para prema nadređenom članu (voditelju) izgrađuje radi ostvarenja zajedničkog tla na kojem se prepoznaju usklađena mišljenja u vezi s predmetom govorenja.

Apsolutna bliskost, kao konverzacijski fenomen kojim se izriče visoka uključenost u tok konverzacije, ostvaruje se u TCU 42.

TCU 34: Gm3: onda budi. ja sam u pozadini. ćutim. ne komentarišem. i naglo se sklonim. onda uhh-

TCU 41: ! ! (0,792) Vm1: šta. više se sklonio. nego što ga je on smijenio.

TCU 35: $\quad(0,502) \mathrm{Gm} 3$ : pred $^{\star}$ - više se on sklonio. javno. prije smjene. nego što je dodik smijenio. (...)

Korpus, intervju Vm1/Gm5

Navedeni primjer također pokazuje referencijsko preslikavanje identičnih dijelova TCU jedinica kako bi se iskazala podrška, odnosno slaganje sa sugovornikom. Prepoznajemo ga i u smjeru od podređenoga člana konverzacijskoga para prema nadređenome.

Primjeri zastupljenosti referencijske veze koji se također mogu svrstati u funkciju govorne podrške, odnosno ojačanja međusobne konverzacijske veze, svakako su i oni u sistemu susjednih parova. U konverzacijskoj strukturi televizijskog intervjua to su inkoativni i sativni, uglavnom dvodijelni pozdravni izričaji ili riječi zahvale za gostovanje. Njihova funkcija posebno je uočljiva kada izostane uobičajena reakcija na prvi dio takve dihotomije.

TCU 1: $\quad$ Vm1: predsjednik predsjedništva bosne i hercegovine. bakir izetbegović. dobro veče gospodine predsjedniče.

TCU 1: $\quad(0,180)$ Gm1: dobro veče.

Korpus, intervju Vm1/Gm1, korpusna jezgra 
TCU 44: Vž2: gospođo pusić- hvala Vam lijepa što ste govorili za al jazeeru.

$(0,206)$

TCU 43: $\quad$ Gž3: hvala Vama.

Korpus, intervju Vž2/Gž3, dodatak jezgri

\section{Funkcija ojačanja vlastitoga iskaza kod podređenoga člana konverzacijskoga para}

Podređeni član konverzacijskoga para u hijerarhijski asimetričnoj konverzaciji na tom položaju, $u$ odnosu na nadređenoga člana, ima manje konverzacijskih resursa kojima bi mogao raspolagati. Izgrađivanje referencijske veze s dijelovima prethodnih govornih priloga u korpusu je prepoznato i u funkciji ojačanja vlastitoga iskaza (općenito, slabiji položaj govornika u konverzacijskom paru pretpostavka je da su i njegovi iskazi slabiji, odnosno da su više podložni primjeni mehanizama konverzacijskih prekida od strane nadređenoga člana). Ta se funkcija obično realizira u dvodijelnoj strukturi, kao reakcija na prvi dio u kojem se postavlja pitanje ili traži stav o predmetu govorenja; drugi je dio odgovor na to pitanje:

TCU 2: Vž2: da. pa kako gledate na to da jedna strana nameće političke predstavnike drugoj strani.

$(0,076)$

TCU 2: $\quad$ Gž3: to nije dobro. na to- gledam na to negativno.

Korpus, intervju Vž2/Gž3, dodatak jezgri

TCU 23: $\quad$ V̌̌2: je li hrvatska dala podršku opozicijskim snagama.

$(0,428)$

TCU 24: $\quad$ Gž3: hrvatska je dala prvo pomoć izbjeglicama. (...)

Korpus, intervju $V \check{2} 2 / G z ̌ 3$, dodatak jezgri 
TCU 26: Vž2: najavili ste ukidanje veleposlanstava. odnosno diplomatsko-konzularnih predstavništava. nekih. međutim- spominje se otvaranje veleposlanstva u kataru. je li to točno.

TCU 26: $\quad(0,389)$ Gž3: točno. točno je otvaranje veleposlanstva u kataru.

Korpus, intervju Vž2/Gž3, dodatak jezgri

TCU 41: Vž2: je li politički korektno- da potpredsjednik- uhh- vladekojem se sudi u mađarskoj- bude u nadzornom odboru tvrtke koju je napravio mađar.

TCU 40: Gž3: politički- to nema veze sa političkom korektnošću. (...) Korpus, intervju Vž2/Gž3, dodatak jezgri

TCU 45: Vm2: gdje se u cijeloj toj priči nalazi branimir štulić.

TCU 48: $\quad(0,112)$ Gm4: branimir štulić- koji je veliki važan umjetniktalentiran čovjek- se ne nalazi nigdje. zato jer je- uhh- zaštita dobrovoljna. on nije državljanin republike hrvatske. dakle mogao bi biti štićen od zampa samo onda ako bi to bilo dogovoreno preko njegovog matičnog društva. on nije član nijedne organizacije. uhh- u parizu se vodi lista. svjetska lista autora. iz koje je vidljivo da on nije član nijedne organizacije. ali to naravno ne znači da se njegova prava mogu zloupotrebljavati. vidim da je ušao u spor sa jednom našom izdavačkom kućom. i ako je točno da su bez dozvole uzeli njegova djela- on će dobiti spor.

Korpus, intervju Vm2/Gm4, korpusni dodatak

TCU 48: Vm2: jeste li Vi u kakvu kontaktu s ninoslavom pavićem.

TCU 51: $\quad(0,239) \mathrm{Gm} 4$ : s ninoslavom pavićem sam recimo u godinu dana čuo ili vidio jedno tri ili četiri puta barem.

Korpus, intervju Vm2/Gm4, dodatak jezgri

TCU 51: Vm1: pa zašto Vi o tome ne govorite. $0^{\star}$ - to su Vam ()- 
TCU 48: $\quad$ ! $\quad(0,925) \mathrm{Gm} 3$ : pa govorim evo. govorim. rek'o sam- i govorio sam neko veče na medijima na kojima mogu. sve ove ključne reforme. i odbrane. i- uh- pe de vea. poreza. glasali su es en es deovi ljudi za njih. to samo name*- ali šta možete kad ne možete doći na javni servis po osam godina. kol'ko ja nisam mog’o doći na javni servis. na radio televiziju republike srpske. i kad ne možete čuti drugačije mišljenje.

TCU 52: $\quad(0,186)$ Vm1: osam godina.

TCU 49: $\quad(0,623)$ Gm3: nikad- osam godina već. pa do neki dan. kad sam dobio poziv. vjerovatno sad narednih osam neću više dobiti ponovo.

Korpus, intervju Vm1/Gm3, korpusna jezgra

TCU 45: Vm1: mislite da- da- da se time radmanović i- um- igor. uhdistanciraju od njega.

TCU 40: $\quad(0,566) \mathrm{Gm} 3$ : pokušavaju da se distanciraju. ali nisam siguran da će se uspjeti distancirati.

Korpus, intervju Vm1/Gm3, korpusna jezgra

U svim se navedenim primjerima uočava da se preslikavanje TCU koja pripada voditelju / voditeljici koristi kao svojevrsna "odskočna daska" s koje podređeni član konverzacijskog para započinje svoju TCU. Tome u prilog posebno idu brojni primjeri kada se preslikava dio TCU koji je kod nadređenoga člana na kraju njegove TCU, a kod podređenoga člana na početku TCU.

\section{Funkcija očuvanja ili poticanja konverzacijskog toka}

U prethodno navedenim primjerima (za drugu funkciju koju ovdje prepoznajemo) uočljivo je da je riječ o strukturi susjednih parova pitanje / odgovor, pri čemu referencijska veza s nadređenim članom konverzacijskog para funkcionira kao ojačanje potvrdnog ili negativnog traženog odgovora ili izricanje sumnje.

TCU 37: Vž1: osim- um- košarke- bavili ste se na neki način- ustvari svirate gitaru. je li tako. 
TCU 27: $\quad(0,162) \mathrm{Gm} 1$ : sviram je i danas.

TCU 38: $\quad(0,333)$ Vž1: svirate i danas gitaru. kada ste počeli.

Korpus, intervju $V \check{z} 1 / G m 1$, korpusna jezgra

TCU 35: Gm1: on je- on je čak i zarađivao na tome. kao mladić. jest. jest. svirao po kafanama. i zarađivao po neku paricu ( ).

TCU 49: $\quad=(1,119)=$ Vžl : zarađivao. je l'.

Korpus, intervju Vž1/Gm1, korpusna jezgra

TCU 50: Vž1: ne. čisto Vas to pitam- evo- uh- američki predsjednik. je li tako. klinton. on je- uhh- svirao (ovom)-

$(0,580)$

TCU 36: $\quad$ Gm1: da. nedavno je- čak i obama nešto pjeva. a i klinton je svirao saksofon.

TCU 51: $\quad(2,581)$ Vž1: da. i obama često svira. uhh- hrvatski predsjednik isto. u svakom prilikom svira. svira- ovaj- klavir. a evo-

TCU 37: $\quad$ Gm1: morat ću i ja prosvirati onda. (nema druge).

Korpus, intervju Vžl/Gm1, korpusna jezgra

TCU 15: Gž1: (...) znači eto- od svih tih silnih- različitih potpuno čakjeste. sve su ostalo čak društvene nauke. ja sam se ipak odredila za medicinu.

Vž_01: $\quad(1,287)$ Vž1: za medicinu. a imali ste još u ranoj mladostidakle te neke ambicije. volju i želju da pišete. bili ste i novinarka. još iz osnovne škole. je li tako.

Korpus, intervju Vž1/Gžl, korpusna jezgra

TCU 14: Vm1: svetlana. um- ne mogu sad da govorim o tome. nekako mi to bezveze da govorim. ali negde diskretno moram da napomenem. Vi ste danas došli iz banjaluke samo zbog ove emisije. i vratit ćete se tamo. i moram da kažem to. i bez dnevnica. honorara. to ste tako odbijali. šta je Vaš motiv. uhh- da- dada- da- tako glasni budete. šta je Vaša briga. to iz neke brige radite. iz interesa nije očigledno. ( ) 
TCU 13: $\quad(0,943)$ Gž2: pa interesa nema. to može svako da proveri. koju imovinu imam. ima više dugova nego imovine. odmah da kažem. dužna sam svega. ovaj- imam kredit. imam svašta nešto. nego- šta je motiv. (...) meni ovo sve liči- uh- uh- verovatno ste to imali u detinjstvu. kad ulete tri dečkića. pa istuku jednog. pa su oni sad kao mangupi. e meni ova država liči na to. da su uvatili neki. i tuku one slabije. i mi svi kao vidi mangupa. e to je ono što mene tera. da kažem. da radim ovo što radim. i da dođem i kod Vas. putujem. to je ono- nemojte. niste baš mangupi da me tučete. vi uvatili policiju. medije. sve stavili pod kontrolu. i sad sam ja- je l da. budala. a vi mangupi što mene prebiste živu. ma ne može to baš tako.

TCU 15: $\quad(0,551)$ Vm1: nećete vjerovati. ja sam neku noć tak - upravo tako definisao stanje i situaciju u bosni i hercegovini. igra- igra- igra dječaka. koji- koji su sada dočepali se vlasti. i tako dalje. ali to su opasne igre. zavađanje naroda.

TCU 15: (3.431) Gž2: pa opasne igre. zato što obično dobijamo pa opasne igre. zato što obično dobijamo- uh- kompleksirane osobe

Korpus, intervju Vm1/Gž2, korpusna jezgra

Upravo s obzirom na izricanje referencijske veze nositelja konverzacijskoga para sa sugovornikom (gostom ili gošćom), tu pojavu kod nositelja intervjua prepoznajemo u ovoj trećoj funkciji, prepoznatljivoj u prethodno navedenim primjerima - očuvanja (ili poticanja) konverzacijskoga toka. Nadređeni član konverzacijskoga para ima odgovornost za usmjeravanje konverzacijskoga toka i održavanje konverzacijske interakcije te time što gradi takvu vezu s prethodnim govornim prilozima "raspiruje" konverzacijski tok, odnosno konverzaciju održava "živom" i dinamičnom. Te su pojave suprotne dispreferencijskim iskazima koji su obično pokazatelj konverzacijske smetnje. Referencijsko preslikavanje prethodne TCU ili njezinoga dijela obično dolazi u paru s kraćim pitanjem fatičke naravi. 


\section{Funkcija pojašnjavanja ili dopune informacije}

Referencijska veza može se prepoznati u funkciji provjere prethodno rečenog, odnosno funkcionira kao zahtjev za pojašnjenje. Također je riječ, kao i u prethodnoj (trećoj) funkciji, o voditeljevom ponavljanju prethodne TCU, no s tom razlikom da imamo drukčiju, upitnu intonaciju, odnosno, preslikana TCU nije fatičke naravi nego se postavlja u strukturu susjednih parova "pitanje - odgovor" (TCU 17 u primjeru pokazuje da je zaista riječ o pitanju jer se poslije takve TCU postavlja dodatno, direktno pitanje). Funkciju koju imenujemo pojašnjavanjem ili dopunom informacije prepoznajemo u sljedećim primjerima:

TCU 3: Vm2: uhh- čit’o sam negdje da imate dosta često goste u kući. odnosno kada ste Vi doma- da ovi gosti Vaši gledaju da li je svjetlo kod Vas. i onda ovisno o tome- ovaj- dođu ili ne dođu. uhh- želim Vas pitati za neke druge goste. jesu li Vam bili ovi gosti koji sada dolaze po službenoj dužnosti. popisivači. $(0,103)$

TCU 3: $\quad$ Gž3: nisu još.

TCU 4: $\quad(0,360)$ Vm2: nisu.

TCU 4: $\quad(0,242)$ Gž3: nisu još.

Korpus, intervju Vm2/Gž3, dodatak jezgri

TCU 61: Vm1: eto- šta ste- šta ste poželjeli.

$(0,112)$

TCU 49: Gm2: zdravlje.

TCU 62: $\quad(0,129)$ Vm1: zdravlje.

$(0,449)$

TCU 63: $\quad$ Vm1: pa da. najpreče je zdravlje.

Korpus, intervju Vm1/Gm2, korpusna jezgra

TCU 11 Gž1: zlata jelinek.

TCU 17 (0,753) Vm1: zlata jelinek. (je li $V^{*}$-) jelinek. čije je to prezime. $(0,225)$ 
TCU 12: Gž1: to je češko prezime.

TCU 18: $\quad=(0,618)=V m 1$ : češko.

Korpus, intervju Vm1/Gž1, korpusna jezgra

TCU 5: $\quad$ Gm1: možda je tako. mislim da ipak želi u evropu.

TCU 6: $\quad(0,160)$ Vm1: ipak želi.

Korpus, intervju Vm1/Gm3, korpusna jezgra

Referencijalnost i funkcija pitanja / zahtjeva može se ostvariti i zasebnim direktnim pitanjem, koje se sastoji od preslikane TCU:

TCU 24: $\quad$ Gm_03: pa to je prirodno.

TCU 33: $\quad(\|)$ Vm_01: zašto je prirodno.

Korpus, intervju Vm1/Gm5, korpusni dodatak

TCU 19: Gž3: (...) dakle kakva god presuda bila- ova koja bude objavljena ovaj mjesec- biti će nepravomoćna. i neće biti završetak procesa. i mislim da je to važno i za sve potencijalne političke korisnike situacije. da to zapamte. i za sve potencijalne osobne korisnike. kojih također ima. koji nastoje sa sebeuhh- nekako- odvratiti pozornost. dižući neopisivu galamu. i koristeći se- gotovinom i situacijom u hagu.

TCU 21: $(0,298)$ Vm2: e da Vas odmah pitam. mislite li Vi- kada koristite ovdje riječ potencijalno- pa da je i ja upotrijebim. ovaj- mislite li da je imaju- potencijala- uhh- destabilizirati stanje u zemlji.

Korpus, intervju Vm2/Gž3, dodatak jezgri

Sažimajući rezultate o referencijskim vezama govornih priloga učesnika konverzacije, došlo se do sljedeće tabele s pripadajućim pojašnjenjima: 
Tabela 3: Rezultati analize referencijalnosti TCU jedinica

u korpusnoj jezgri i dodatku jezgri

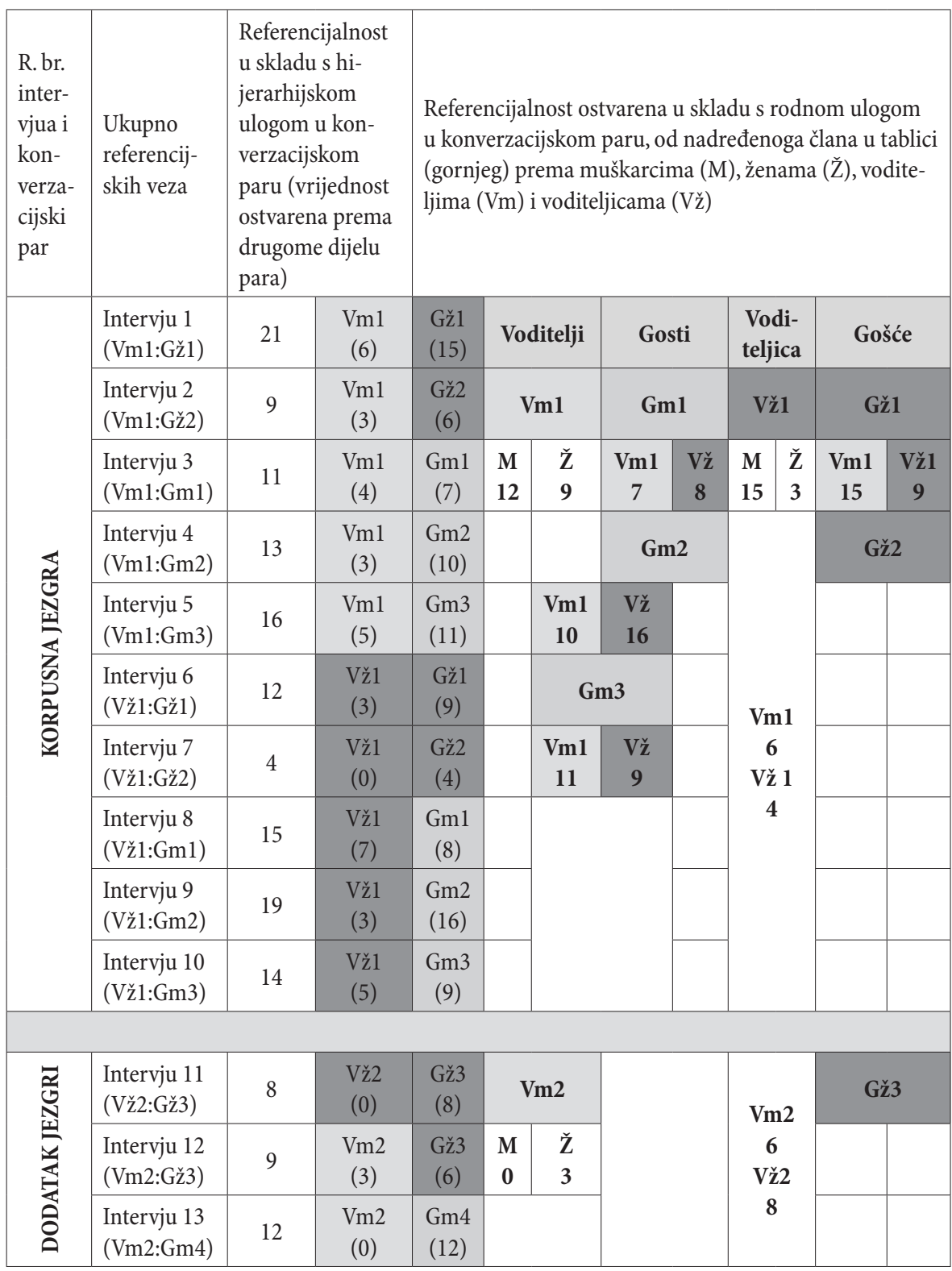

Iako konverzacijski analitičari podozrivo gledaju na bilo koji oblik kvantifikacije rezultata, većina se tih istraživanja, ipak, u manjoj ili većoj mjeri naslanja i na metodologiju korpusne lingvistike. $U$ analizi 
konverzacijskoga fenomena referencijske veze TCU jedinica, zbirni tabelarni prikaz otkriva nam sljedeće:

1. S položaja voditelja intervjua ne pokazuje se sistematična rodno uvjetovana primjena ovoga fenomena jer su vrijednosti vrlo bliske kada je riječ o vezi s govornim prilozima i gošći i gostiju. Donekle je upadljivo da u razgovoru voditelja $\mathrm{Vm} 2$ s gostom Gm4 ta pojava u cijelosti izostaje, a u njegovom razgovoru s gošćom Gž3 javlja se svega 3 puta.

2. S položaja voditeljice intervjua nazire se prevaga u pojavnosti referencijalnosti s muškim gostima (7, 3 i 5 puta), dok je u njezinom razgovoru s dvjema gošćama u jednom slučaju referencijalnost izostala, a u drugom se javila 3 puta, što je identično najnižoj vrijednosti u njezinim intervjuima s muškarcima.

3. Muškarci su kod voditelja Vm1 zastupljeni vrijednostima 7, 10 i 11 , što je neznatno manje negoli u njihovom razgovoru s voditeljicom, gdje su te vrijednosti 8, 16 i 9.

4. Gošće su u razgovoru s voditeljem Vm1 zastupljene vrijednostima 15 i 6, što je ujedno i najveće odstupanje u okvirima korpusa jer su iste vrijednosti, zbirno gledano, manje u razgovoru s voditeljicom (tu iznose 9 i 4). Gošća Gž3 u razgovoru s voditeljicom Vž2 referencijalnost pokazuje 8, a u razgovoru s voditeljem Vm2 6 puta, što su vrlo bliske vrijednosti.

5. Zbirni rezultati pokazuju sljedeće:

a) Neznatno je više ukupnih referencijskih veza u intervjuima kojima je nositelj voditelj (70) naspram onima kojima je nositeljica voditeljica (64).

b) Uočljivo je da je ukupan broj referencijskih veza koje muškarci gosti grade s nositeljima intervjua donekle veći od broja takvih veza od gošći prema istim nositeljima intervjua; taj je odnos 61 (gosti muškarci) : 48 (gošće).

c) U svim intervjuima dosljednom se pokazuje pojava da je broj referencijskih veza uvijek veći od sugovornika prema nositelju intervjua negoli u obrnutom smjeru. Tu pojavu 
razumijevamo u cijelosti u skladu s asimetrijom međusobnoga odnosa u konverzacijskom paru medijskoga diskursa, odnosno težnjom da se istakne veza s onim o čemu govori nadređeni član u konverzacijskome paru.

Dakle, pojednostavnjeno, uzimajući u obzir ograničenost korpusa istraživanja, čini se da se referencijske veze češće javljaju u intervjuima kojima su nositelji muškarci, te da su muškarci oni koji, zbirno gledano, više primjenjuju tu konverzacijsku praksu. Također se uočila blaga razlika u korist gošći kada gostuju kod voditelja, negoli kada su kod voditeljice. Naznake tih rezultata ne podudaraju se sa mišljenjem koje o konverzacijskom dinamizmu ističe Kalčik (1975. u Sunderland 2006: 118-119) jer su se dobili suprotni rezultati.

Kategoriji roda pristupa se kao omnirelevantnoj kategoriji, tj. kategoriji nadređenoj svim ostalim diskursnim ulogama. Sekvencijski slijed govornih priloga analiziran je u skladu s polazištem da postoje rodne varijacije u primjeni referencijalnosti radi uspostavljanja i ojačanja međusobne konverzacijske veze. Takve su pojave također kvantitativno analizirane, ali se uz taj dio analize došlo i do moguće funkcionalne klasifikacije u pojavnosti referencijalnosti te se tako izdvajaju:

1. funkcija podrške sugovorniku (ponavljanje dijela ili cijele TCU prethodnoga govornika s ciljem očuvanja "zajedničkoga tla”);

2. funkcija ojačanja vlastitog iskaza (ta se funkcija prepoznaje kod podređenih članova konverzacijskih parova, i to uz naglašavanje potvrdnog ili odričnog stava o prethodno rečenom; realizira se u dvodijelnoj strukturi - ponavljanju dijela TCU i odgovoru / reakciji na prethodni iskaz);

3. funkcija poticanja konverzacijskog toka (ta se funkcija ostvaruje s položaja nositelja intervjua i to tako što se naglašava prethodno rečeno ili dio rečenog i obično bude praćeno kraćim privjesnim pitanjem ili sličnim jezičnim sredstvom koje ima fatičku funkciju);

4. funkcija pojašnjavanja ili zahtjeva za dopunu informacije (ta je funkcija po naravi "eho iskaz" koji podrazumijeva potpuno 
preslikavanje prethodne TCU, no njezino izricanje uz drukčiju, upitnu intonaciju, pri čemu takvi iskazi funkcioniraju kao prava pitanja, a često su ojačani upravo dodatnim direktnim pitanjima).

Analiza korpusa pokazala je, uzimajući u obzir njegovu ograničenost, da se referencijske veze češće javljaju u intervjuima voditelja Vm1, da muškarci češće koriste referencijske veze u konverzaciji te da i gošće, neznatno više, koriste referencijske veze u razgovoru s voditeljem Vm1 negoli kada gostuju kod voditeljice Vž1.

Također je uočeno da su muškarci oni koji, u cijelosti gledano, više koriste referencijske veze negoli gošće. Upadljivo je da su ovi rezultati drukčiji od onih koje ističe Kalčik (1975. u Sunderland 2006: 118-119), analitičarka koja se prva usmjerila na taj konverzacijski fenomen, no usporedba je vrlo uvjetna, s obzirom na metodološke i korpusne razlike u tim istraživanjima.

\section{Literatura}

Aljukić, Bernes (2015): Jezik i rodne razlike u medijskom diskursu: konverzacijska analiza televizijskih intervjua, doktorski rad, Sveučilište Josipa Jurja Strossmayera u Osijeku, Filozofski fakultet, Osijek.

Bousfield, Derek; Locher, Miriam (2008): "Impoliteness and power in language”, u: Bousfield, Derek; Locher, Miriam (ur.) Impoliteness in Language. Studies on its Interplay with Power in Theory and Practice, Mouton de Gruyter, Berlin - New York, 1-16.

Coates, Jeniffer (2004): Women, Men, and Language: A Sociolinguistic Account of Gender Differences in Language, Pearson Education, Harlow.

Eckert, Penelope; McConnell-Ginet, Sally (2003): Language and Gender, Cambridge University Press, Cambridge.

Hutchby, Ian; Wooffitt, Robin (2002): Conversation Analysis, Principles, Practices and Applications, Polity, Cambridge - Malden - Oxford.

Lakoff, Robin Tolmach (2004): Language and woman's place. Text and commentaries, Revised and expanded edition, ur. Mary Bucholtz, Oxford University Press, Oxford. 
Maltz, Daniel; Ruth, Borker (1982): "A cultural approach to male-female miscommunication", u: Gumperz, John (ur.) Language and Social Identity, Cambridge University Press, Cambridge, 196-216.

Mills, Sara (2003): Gender and Politeness, Cambridge University Press, Cambridge.

O'Barr, William; Atkins, Bowman (1980/2014): “'Women's language' or 'powerless language"'? u: Gita DasBender (ur.) Language: A Reader for Writers, Oxford University Press, Oxford, 401-407.

Speer, Susan; Stokoe, Elizabeth (2011): "An introduction to conversation and gender", u: Speer, Susan; Stokoe, Elizabeth (ur.) Conversation and Gender, Cambridge University Press, Cambridge, 1-28.

Sunderland, Jane (2006): Language and Gender. An advanced resource book, Routledge, London - New York.

Talbot, Mary (2003): "Gender Stereotypes: Reproduction and Challenge", u: Holmes, Janet; Meyerhoff, Miram (ur.) The Handbook of Language and Gender, Blackwell Publishing, Maiden - Oxford - Melbourne - Berlin, 468-486.

Wooffitt, Robin (2005): Conversation Analysis \& Discourse Anaylsis, A Comparative and Critical Introduction, SAGE Publications, London Thousand Oaks - New Delhi. 


\title{
Gender-marked referentiality in the media discourse
}

\begin{abstract}
The range of conversational strategies that highlight the presumed disparities in communication styles between men and women also recognizes the conversational phenomenon of referentiality has been observed in the 1970s - that women, more often than men, at the beginning of their statements explicitly emphasize what has been said before and thus build a conversational core. The aim of the paper, therefore, is to determine the presence and conversational functions of such a phenomenon in media discourse by analyzing conversational pairs in television interviews represented with gender equal guests and presenters. Through conversational and discourse analysis and the use of the computer software Elan, a useful tool for transcription and annotation, we gained the result of two-layer corpus of 13 interviews, consisting of about 73,000 words. With all the limitations of the corpus and the methodology that this approach carries, the analysis shows that four possible conversational and pragmatic functions of referentiality are recognizable in media discourse, with the difference that they are more often observed in male conversational pairs. Referentiality in media discourse implies the following pragmatic functions: supporting the interlocutor, strengthening one's statement, encouraging the flow of conversation and clarifying or requesting additional information. This is more often recognized in interviews with a male presenter and with male conversational pairs.
\end{abstract}

Keywords: gender, language, TV interviews, referentiality, TCU

\section{Izjava autora o nepostojanju sukoba interesa i poštivanju općih etičkih kodeksa:}

Autor potvrđuje da ne postoji nikakav stvarni ili mogući sukob interesa vezan za ovaj tekst te da je tekst napisan u skladu s etičkim kodeksima prema preporukama COPE (Committee of Publishing Ethics). 